\title{
HUMAN TOXOPLASMOSIS OUTBREAKS AND THE AGENT INFECTING FORM. FINDINGS FROM A SYSTEMATIC REVIEW
}

\author{
Luciana Regina MEIRELES(1), Claudio Cesar Jaguaribe EKMAN(1), Heitor Franco de ANDRADE JR.(1,2) \& Expedito José de Albuquerque LUNA(1)
}

\begin{abstract}
SUMMARY
Toxoplasmosis, a worldwide highly prevalent zoonotic infection, is transmitted either by the oocysts, from water and soil, or the tissue cysts, in raw or undercooked infected meat, of Toxoplasma gondii. An ongoing debate is whether there are differences between the clinical and epidemiological characteristics of the outbreaks due to one or the other infective form of the agent. We performed a systematic review, recovering 437 reported outbreaks of which 38 were selected. They were complete reports containing ascribed Toxoplasma infecting form, and clinical and demographic data. There was no gender or age group selection in the outbreaks, which were described more often in the Americas. A large number of individuals were affected when oocysts, associated with soil and water contaminated with cat feces, were considered the transmission source. Onset of symptoms occurred early when the infection was ascribed to meat tissue cysts (11.4 \pm 6.7 days) with sharpened temporal distribution of cases, while a broader and prolonged appearance of new cases was observed when oocysts in water were the source of the infection ( $20 \pm 7$ days, $p<0.001)$. Such information may be useful in the design and implementation of control strategies.
\end{abstract}

KEYWORDS: Toxoplasmosis; Toxoplasma gondii; Outbreaks; Oocyst; Cyst; Foodborne diseases; Waterborne diseases.

\section{INTRODUCTION}

Toxoplasmosis is one of the most prevalent parasitic infections worldwide, affecting at least one billion people and a large fraction of meat-producing animals ${ }^{43}$. The disease is caused by the Apicomplexa protozoon Toxoplasma gondii, which has felids as definitive hosts and all warm-blooded animals as intermediate hosts, including man ${ }^{18}$. The transmission occurs by ingestion of either water, vegetables or soil contaminated with oocysts from cat feces; or raw, or undercooked, meat containing viable tissue cysts, characterizing this disease as a foodborne zoonosis $^{43}$.

Usually benign and/or asymptomatic, $T$. gondii infection can cause ocular disease in a small fraction of infected individuals, or severe disease in congenitally infected fetuses and immunosuppressed patients. Toxoplasmosis prevalence varies from 10 to $90 \%$ of the adult population, according to each region or food habits ${ }^{43}$.

In Brazil, 50 to $80 \%$ of adults have been infected with Toxoplasma ${ }^{16}$, demonstrating the need for greater emphasis on measures to prevent the disease, which involve meat and water quality control ${ }^{20,43}$. Several toxoplasmosis outbreaks have been reported in Brazil, the first one being described in the 1960s, in a university ${ }^{31}$. After this report, several others have been described in all regions of the Brazilian subcontinent, as in the Midwest ${ }^{36}$, Southeastern region ${ }^{22}$, Amazon/North R-region ${ }^{6}$ and South -region ${ }^{3,11}$, attributing the outbreaks to several infective forms of $T$. gondii. These outbreaks have been mainly related to clusters of cases, in families or other small population groups, but some outbreaks have also been described in larger populations, such as small cities ${ }^{16}$ or industrial plants $^{22}$. However, little is known regarding severity of the disease associated to the infective form of the agent. We decided to perform a systematic revision of reported outbreaks of human toxoplasmosis in medical literature, in order to clarify whether the infecting form of the protozoan is related to the clinical and epidemiological characteristics of the outbreaks. Such information may be useful in the design and implementation of control strategies.

\section{MATERIALS AND METHODS}

The systematic review was performed according to the Cochrane guidelines 25 . We have searched the keywords "human toxoplasmosis outbreak" in the following public health bibliographical databases: Embase, Food Sciences \& Tech Abstracts, Lilacs, PubMed, Scopus and Web of Science. We have also searched the Cochrane Reviews Database, and the collections of the Brazilian public health surveillance bulletins, published by the Brazilian Federal Ministry of Health ("Boletim Eletrônico Epidemiológico"), and by the State Health Department of Sao Paulo ("BEPA - Boletim Epidemiológico Paulista"). We have also

(1) Universidade de São Paulo, Instituto de Medicina Tropical de São Paulo, São Paulo, SP, Brasil.

(2) Universidade de São Paulo, Faculdade de Medicina, São Paulo, SP, Brasil.

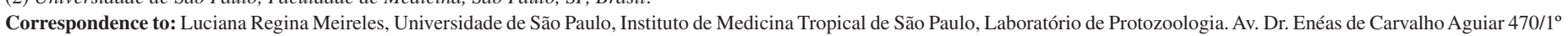
andar, 05403-000 São Paulo, SP, Brasil. Tel/Fax: +55+11+30617010. E-mail: 1rmeirel@usp.br 


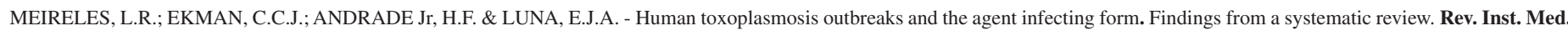
Trop. Sao Paulo. 57(5): 369-76,2015.

included in our search meeting and congress abstracts retrieved from the above databases either in English, Portuguese or other languages. We selected and included only those reports that adequately described human toxoplasmosis outbreaks, summarized the clinical characteristics of the affected patients, and also suggested or defined the infective form of $T$. gondii. We excluded reports of outbreaks that only presented description of clinical cases of $T$. gondii infection without epidemiological data or parasitological studies about the infective form associated to the outbreak. Duplicate reports of the same outbreak were checked and the more complete report was included for subsequent analysis. All selected reports were analyzed for identification of the agent's infective form responsible for the outbreak, such as tissues cysts, oocysts or tachyzoites. In each report, we have searched for the source of the agent: water, vegetables, meat or contact with soil. Number of cases, their gender, age and symptomatology were collected, as well as the method used for confirmation of the diagnosis. The affected groups and population at risk were also researched in each outbreak report, as well as their distribution in time and space. The attributed incubation period in days and the clinical presentation of the acute infection, if symptomatic or asymptomatic, were considered as informed by the authors' description in each report.

Taking into account these inclusion and exclusion criteria, each report was carefully read and the data were recorded by two independent readers, composing a database analyzed by sorting according to the outbreak's infective form of $T$. gondii defined by the author of the report. We did not attempt to combine the data for a meta-analysis, however, it was possible to estimate combined figures for some clinical and epidemiological variables, which are presented in Table 3. Quantitative variables were analyzed by ANOVA or, in the absence of variance homogeneity, by the Kruskal-Wallis test. Qualitative variables were analyzed by the Chisquare test. Differences were considered significant when the probability of equality was less than $5 \%(p<0.05)$.

\section{RESULTS}

Research and selection of outbreak reports: We performed the research of human toxoplasmosis outbreak reports, in the above mentioned databases, recovering 431. We also checked citations from complete articles and found another six, resulting in 437 reports. We selected 269 (62.4\%) outbreak reports after the exclusion of 162 that were duplicated. The next step was data quality; we excluded 214 incomplete, partial, limited or merely descriptive reports, especially those found in Food Sciences \& Tech Abstracts database. We selected 55 (20.40\%) available reports that fulfilled all the inclusion criteria for the study, as described in the Materials and Methods section, but 13 had incomplete data from affected patients, six focused only on the differential diagnosis with other food or waterborne diseases, six were incomplete regarding the parasitological data and four were only related to the characterization of the agent and laboratorial data, resulting in 38 outbreaks reports available for systematic review (Table 1). The algorithm of this process is shown in Figure 1.

Outbreak analysis: The study design, in most reports, was merely descriptive (31/38) in addition to four case control studies, two retrospective cohorts and one case series. Selected outbreaks were described in the Americas (27/38) equally distributed in North (14/38) and South (13/38) America.
Demographic and general clinical findings are shown in Table 2. Gender predominance was informed in all reports, male being more frequent in 21 of 38 reports. Water was implicated as the source in $21 \%$ $(8 / 38)$ of the outbreaks, contact with soil in $26.3 \%$ (10/38), and raw vegetables in $5.3 \%(2 / 38)$. Meat consumption, raw or undercooked, was the source in $44.7 \%(17 / 38)$ of the outbreaks. The ingestion of cysts in intrinsically contaminated meat has been frequently reported in human toxoplasmosis outbreaks in Australia ${ }^{13,37}$, Brazil $^{3}, \mathrm{Canada}^{33}, \mathrm{Korea}^{9}$ and the USA ${ }^{28}$. However, oocysts have also been implicated in several toxoplasmosis outbreaks, ascribing the transmission to environmental contamination ${ }^{4,12,44}$. Oocyst contamination of drinking water was associated with large outbreaks in $\mathrm{Canada}^{4}$ and Brazil ${ }^{12}$. Tachyzoites, the rapid growing form of $T$. gondii, found in acute infection, have been rarely implicated as a source in outbreaks, but these forms can be found in raw milk. Outbreaks associated with raw goat milk ingestion were described in $\mathrm{Brazil}^{8}$, $\mathrm{USA}^{39}$ and United Kingdom ${ }^{41}$.

Quantitative data are presented in Table 3. Those data have shown a large variability in the number of affected cases and population at risk, suggesting differences between epidemiological profiles, according to the infective form involved in the outbreak. Interestingly, the proportion of infected people and the proportion of symptomatic cases, among the infected, presented low dispersion, suggesting a more uniform distribution pattern of the disease. The incubation period reported by the authors is around twenty days, but with a higher dispersion.

Gender and age groups were similar and independent of the type of source. Outbreaks associated with water and soil contact were attributed mainly to oocysts, while meat consumption was attributed to tissue cysts, as expected. No differences in general clinical picture were observed, but quantitative data showed that the number of cases was larger in outbreaks attributed to oocysts, while cyst and tachyzoites were related to clustered and smaller outbreaks (Fig. 2C). Despite this fact, the disease spread, shown by the proportion of infected or symptomatic cases, was very similar in each attributed source. We have failed to demonstrate that a more widespread source, as oocysts in water, resulted in large populations at risk, probably due to the limited number of reports dealing with water contamination. The incubation period was shorter in outbreaks attributed to cysts, with a mean of less than 12 days, while oocysts associated outbreaks presented longer incubation periods, with a mean of 20 days.

The summary of the outbreaks' quantitative data, related to the different infective forms of the agent, is shown in Figure 2. The large affected population is evident for outbreaks with oocysts source, with a few outliers associated to water ingestion (Fig. 2A). On the other hand, oocysts-associated outbreaks in which the source of infection was soil tend to affect a smaller number of people, in a similar way to clusters observed in cysts or tachyzoites-associated outbreaks. There was also a very similar distribution of reports, according to the proportion of infected (Fig. 2B) or symptomatic cases (Fig. 2D), suggesting that the source of infection is unrelated to the clinical profile.

The distribution of the outbreaks' incubation period, according to the attributed infective form of the agent, is presented in Figure 3. As may be seen, a large proportion of oocysts associated outbreaks did not report the incubation period, especially those associated with water, due to the longer survival of this form and difficulty to define the time of ingestion. But the available data was sufficient to show a significantly 
Table 1

Eligible complete reports of human toxoplasmosis outbreaks included in the systematic review

\begin{tabular}{|c|c|c|c|c|c|c|c|c|c|c|c|c|c|}
\hline Year & $\begin{array}{l}\text { Geographical } \\
\text { distribution }\end{array}$ & $\begin{array}{l}\text { Transmis- } \\
\text { sion forms }\end{array}$ & Water & Meat & Vegetable & Soil & $\begin{array}{l}\text { Confirmed } \\
\text { cases }\end{array}$ & $\begin{array}{l}\% \text { Symp- } \\
\text { tomatic }\end{array}$ & $\begin{array}{c}\text { Risk } \\
\text { population }\end{array}$ & $\%$ Infected & I.P (days) & $\begin{array}{l}\text { Dissemina- } \\
\text { tion }\end{array}$ & Articles references \\
\hline 1966 & South America & Cysts & 0 & 1 & 0 & 0 & 110 & 87 & 10.000 & 1,1 & NI & Focal & Magaldi et al..$^{31}$ \\
\hline 1968 & North America & Cysts & 0 & 1 & 0 & 0 & 5 & 100 & 29 & 17 & 7 & Focal & Kean et al. ${ }^{28}$ \\
\hline 1974 & North America & Cysts & 0 & 1 & 0 & 0 & 4 & 50 & 19 & 42 & 10 & Focal & $\begin{array}{c}\text { Center for Disease } \\
\text { Control }^{7}\end{array}$ \\
\hline 1975 & North America & Cysts & 0 & 1 & 0 & 0 & 6 & 83 & 7 & 83 & 12 & Focal & Masur et al. ${ }^{32}$ \\
\hline 1976 & North America & Oocysts & 0 & 0 & 0 & 1 & 10 & 70 & 30 & 33 & 30 & Focal & Stagno et al. ${ }^{42}$ \\
\hline 1977 & Europe & Cysts & 0 & 1 & 0 & 0 & 3 & 66 & $\mathrm{NI}$ & NI & 8 & Focal & Fertig et al. ${ }^{23}$ \\
\hline 1977 & North America & Oocysts & 0 & 0 & 0 & 1 & 37 & 95 & 88 & 42 & 15 & Focal & Teutsch et al. ${ }^{44}$ \\
\hline 1978 & North America & Tachyzoites & 0 & 0 & 0 & 0 & 10 & NA & 24 & 42 & 38 & Focal & Sacks et al. ${ }^{38}$ \\
\hline 1979 & $\begin{array}{l}\text { Central } \\
\text { America }\end{array}$ & Oocysts & 1 & 0 & 0 & 0 & 31 & 91 & 98 & 32 & 20 & Wide & Benenson et al. ${ }^{2}$ \\
\hline 1979 & Oceania & Cysts & 0 & 1 & 0 & 0 & 5 & 40 & 6 & 83 & NI & Focal & de Silva et al. ${ }^{13}$ \\
\hline 1979 & North America & Oocysts & 0 & 0 & 0 & 1 & 9 & 44 & 13 & 69 & NA & Focal & Shenep et al. ${ }^{40}$ \\
\hline 1980 & North America & Cysts & 0 & 1 & 0 & 0 & 3 & 100 & NA & NA & 15 & Focal & Sacks et al. ${ }^{39}$ \\
\hline 1981 & North America & Oocysts & 0 & 0 & 0 & 1 & 6 & 33 & 9 & 67 & NI & Focal & $\begin{array}{l}\text { Luft e Remington } \\
\quad(\text { Outbreak 2) }\end{array}$ \\
\hline 1981 & South America & Oocysts & 0 & 0 & 0 & 1 & 5 & 40 & 6 & 83 & NI & Focal & $\begin{array}{l}\text { Luft e Remington } \\
\quad(\text { Outbreak } 3)^{29}\end{array}$ \\
\hline 1981 & North America & Cysts & 0 & 1 & 0 & 0 & 1 & 100 & 4 & 25 & NI & Focal & $\begin{array}{l}\text { Luft e Remington } \\
(\text { Outbreak 5) }\end{array}$ \\
\hline 1982 & North America & Oocysts & 0 & 0 & 0 & 1 & 2 & 50 & 6 & 33 & NI & Focal & $\begin{array}{l}\text { Luft e Remington } \\
\quad(\text { Outbreak 1) }\end{array}$ \\
\hline 1982 & North America & Oocysts & 0 & 0 & 0 & 1 & 1 & 100 & 5 & 20 & NI & Focal & $\begin{array}{l}\text { Luft e Remington } \\
\quad(\text { Outbreak 4) }\end{array}$ \\
\hline 1983 & South America & Tachyzoites & 0 & 0 & 0 & 0 & 3 & 66 & 5 & 60 & 30 & Focal & Chiari et al. ${ }^{8}$ \\
\hline 1986 & Europe & Cysts & 0 & 1 & 0 & 0 & 3 & 66 & 4 & 75 & NI & Focal & Humphreys et al. ${ }^{26}$ \\
\hline 1987 & North America & Cysts & 0 & 1 & 0 & 0 & 4 & NA & 22 & 36 & 90 & Focal & McDonald et al. ${ }^{33}$ \\
\hline 1988 & Europe & Tachyzoites & 0 & 0 & 0 & 0 & 2 & 100 & 4 & 50 & NA & Focal & Skinner et al. ${ }^{41}$ \\
\hline 1993 & South America & Cysts & 0 & 1 & 0 & 0 & 17 & 100 & NI & NI & 11 & Focal & Bonametti et al. ${ }^{3}$ \\
\hline 1994 & Asia & Cysts & 0 & 1 & 0 & 0 & 3 & 100 & 6 & 50 & NI & Focal & $\begin{array}{c}\text { Choi et al. (Outbreak } \\
1)^{9}\end{array}$ \\
\hline 1994 & Oceania & Cysts & 0 & 1 & 0 & 0 & 12 & 75 & 38 & 32 & 11 & Focal & Robson et al. ${ }^{37}$ \\
\hline 1995 & North America & Oocysts & 1 & 0 & 0 & 0 & 100 & 82 & 321.585 & 0,03 & NI & Wide & Bowie et al. ${ }^{4}$ \\
\hline 1995 & Asia & Cysts & 0 & 1 & 0 & 0 & 5 & 100 & 11 & 45 & 7 & Focal & $\begin{array}{l}\text { Choi et al. (Outbreak } \\
22)^{9}\end{array}$ \\
\hline 1999 & South America & Oocysts & 1 & 0 & 0 & 0 & 113 & NI & NI & NI & NI & Focal & Gattás et al. ${ }^{24}$ \\
\hline 2001 & South America & Oocysts & 1 & 0 & 0 & 0 & 176 & 88 & 2.884 & 6,1 & NI & Wide & de Moura et al. ${ }^{12}$ \\
\hline 2001 & Asia & Oocysts & 1 & 0 & 0 & 0 & 178 & 71 & NI & $\mathrm{NI}$ & NI & Wide & Palanisamy et al..$^{35}$ \\
\hline 2002 & Asia & Oocysts & 0 & 0 & 0 & 1 & 171 & 100 & 1797 & 9,5 & NI & Focal & Doganci et al. ${ }^{15}$ \\
\hline 2003 & South America & Oocysts & 1 & 0 & 0 & 1 & 11 & 100 & 33 & 33,33 & NI & Focal & Demar et al. ${ }^{14}$ \\
\hline 2004 & Asia & Oocysts & 1 & 0 & 0 & 0 & 248 & 100 & $\mathrm{NI}$ & $\mathrm{NI}$ & NI & Wide & Balasundaram et al. ${ }^{1}$ \\
\hline 2004 & South America & Oocysts & 0 & 0 & 0 & 1 & 40 & 85 & 186 & 21 & NI & Wide & Carmo et al. ${ }^{6}$ \\
\hline 2005 & South America & Cysts & 0 & 1 & 0 & 0 & 10 & 100 & 16 & 62,5 & 30 & Focal & de Almeida et al. ${ }^{11}$ \\
\hline 2005 & South America & Oocysts & 1 & 0 & 0 & 0 & 9 & 100 & 800 & 1,2 & NI & Focal & Madeira et al. ${ }^{30}$ \\
\hline 2006 & South America & Cysts & 0 & 1 & 0 & 0 & 6 & 100 & NI & $\mathrm{NI}$ & 6 & Focal & Eduardo et al..$^{21}$ \\
\hline 2006 & South America & Cysts & 0 & 1 & 0 & 0 & 61 & 97 & 315 & 19 & 8 & Focal & Renoiner et al..$^{36}$ \\
\hline 2009 & South America & Oocysts & 0 & 0 & 1 & 0 & 11 & 72 & 45 & 35 & 15 & Focal & Ekman et al. ${ }^{22}$ \\
\hline
\end{tabular}

$\mathrm{NI}=$ not informed; $0=$ is not the source of infection; $1=$ is the source of infection. 


\section{DISCUSSION}

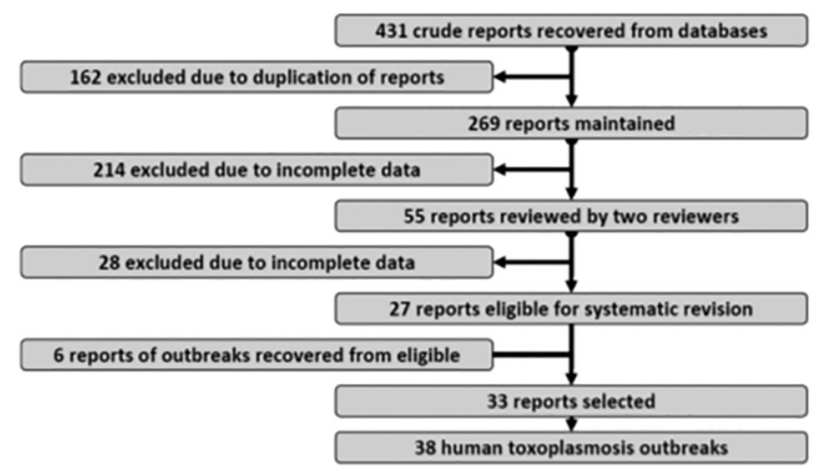

Fig. 1 - Systematic review flowchart.
Our systematic review recovered a large number of outbreak reports, but many of them described the same outbreak or were incomplete. This fact resulted in a small fraction of complete reported outbreaks of human toxoplasmosis; nevertheless, this restricted sample allowed the analysis of the outbreaks as a group and according to the agent form involved. We performed a careful review of citations on recovered reports and this approach allowed the detection of six more outbreaks. This fact demonstrated that the automatic research was excellent, but not a perfect tool, and must be completed by careful personal review.

Gender association was not found in our systematic review, a fact described in some other studies of risk factors for toxoplasmosis ${ }^{27}$. No outbreaks were associated with exposure in slaughterhouses or in meat processing activities, thus our results were randomly distributed and not gender-associated due to an occupational bias. There were descriptions

Table 2

Frequency of reports of categorical variables in the systematic review of human toxoplasmosis outbreaks according to the infective form of T.gondii attributed as source

\begin{tabular}{|c|c|c|c|c|c|}
\hline \multirow[b]{2}{*}{ Variable } & \multirow{2}{*}{$\begin{array}{c}\text { Total \% } \\
\text { [Confidence Interval 95\%] } \\
\text { (n/total) }\end{array}$} & \multicolumn{3}{|c|}{ Infective form } & \multirow{2}{*}{$\begin{array}{l}\text { Significance } \\
\chi^{2}\end{array}$} \\
\hline & & Oocysts & Cysts & Tachyzoites & \\
\hline $\begin{array}{l}\text { Gender as } \% \text { of male } \\
\text { reported predominance }\end{array}$ & $\begin{array}{c}55.26 \% \\
{[38.3-71.4]} \\
(21 / 38)\end{array}$ & $\begin{array}{c}44.44 \% \\
{[21.5-69.2]} \\
(8 / 18) \\
\end{array}$ & $\begin{array}{c}64.70 \% \\
{[38.3-85.8]} \\
(11 / 17)\end{array}$ & $\begin{array}{c}66.67 \% \\
{[9.4-99.2]} \\
(2 / 3) \\
\end{array}$ & NS \\
\hline $\begin{array}{l}\% \text { of less than } 15 \\
\text { year age group } \\
\text { predominance }\end{array}$ & $\begin{array}{c}15.78 \% \\
{[6.0-31.3]} \\
(6 / 38) \\
\end{array}$ & $\begin{array}{c}22.22 \% \\
{[6.4-47.63](4 / 18)}\end{array}$ & $\begin{array}{c}5.89 \% \\
{[0.2-28.7](1 / 17)}\end{array}$ & $\begin{array}{c}33.33 \% \\
{[0.8-90.6]} \\
(1 / 3)\end{array}$ & NS \\
\hline $\begin{array}{l}\% \text { of more than } \\
25 \text { year age group } \\
\text { predominance }\end{array}$ & $\begin{array}{c}44.73 \% \\
{[28.6-61.7](17 / 38)}\end{array}$ & $\begin{array}{c}33.33 \% \\
{[13.3-59.0](6 / 18)}\end{array}$ & $\begin{array}{c}58.82 \% \\
{[32.9-81.6](10 / 17)}\end{array}$ & $\begin{array}{c}33.33 \% \\
{[0.8-90.6](1 / 3)}\end{array}$ & NS \\
\hline $\begin{array}{l}\% \text { of water attributed } \\
\text { reports }\end{array}$ & $\begin{array}{c}21.05 \% \\
{[9.6-37.3](8 / 38)}\end{array}$ & $\begin{array}{c}44.44 \% \\
{[21.5-69.2]} \\
(8 / 18)\end{array}$ & $\begin{array}{c}0 \% \\
{[0-19.5](0 / 17)}\end{array}$ & $\begin{array}{c}0 \% \\
{[0-70.7](0 / 3)}\end{array}$ & - \\
\hline $\begin{array}{l}\% \text { of meal attributed } \\
\text { reports }\end{array}$ & $\begin{array}{c}44.73 \% \\
{[28.6-61.7]} \\
(17 / 38) \\
\end{array}$ & $\begin{array}{c}0.00 \% \\
{[0.0-18.5](0 / 18)}\end{array}$ & $\begin{array}{c}100.00 \% \\
{[80.5-100](17 / 17)}\end{array}$ & $\begin{array}{c}0 \% \\
{[0-70.7](0 / 3)}\end{array}$ & - \\
\hline $\begin{array}{l}\% \text { of vegetables } \\
\text { attributed reports }\end{array}$ & $\begin{array}{c}5.26 \% \\
{[0.6-17.7]} \\
(2 / 38)\end{array}$ & $\begin{array}{c}11.11 \% \\
{[1.4-34.7]} \\
(2 / 18)\end{array}$ & $\begin{array}{c}0 \% \\
{[0-19.5](0 / 17)}\end{array}$ & $\begin{array}{c}0 \% \\
{[0.00-70.8](0 / 3)}\end{array}$ & NS \\
\hline $\begin{array}{l}\% \text { of soil contact } \\
\text { attributed reports }\end{array}$ & $\begin{array}{c}26.31 \% \\
{[13.4-43.1]} \\
(10 / 38)\end{array}$ & $\begin{array}{c}55.55 \% \\
{[30.8-78.5](10 / 18)}\end{array}$ & $\begin{array}{c}0 \% \\
{[0-19.5](0 / 17)}\end{array}$ & $\begin{array}{c}0 \% \\
{[0-70.8](0 / 3)}\end{array}$ & - \\
\hline $\begin{array}{l}\% \text { reports with acute } \\
\text { disease cases }\end{array}$ & $\begin{array}{c}92.10 \% \\
{[78.6-98.3](35 / 38)}\end{array}$ & $\begin{array}{c}94.44 \% \\
{[72.7-99.9](17 / 18)}\end{array}$ & $\begin{array}{c}88.23 \% \\
{[63.6-98.5](15 / 17)} \\
\end{array}$ & $\begin{array}{c}100.00 \% \\
{[29.2-100](3 / 3)} \\
\end{array}$ & NS \\
\hline $\begin{array}{l}\% \text { reports with other } \\
\text { than acute disease cases }\end{array}$ & $\begin{array}{c}9.67 \% \\
{[2.0-25.8](3 / 31)} \\
\end{array}$ & $\begin{array}{c}6.67 \% \\
{[0.2-32](1 / 15)} \\
\end{array}$ & $\begin{array}{c}14.28 \% \\
{[1.8-42.8](2 / 14)} \\
\end{array}$ & $\begin{array}{c}0 \% \\
{[0-84.2](0 / 2)} \\
\end{array}$ & NS \\
\hline $\begin{array}{l}\% \text { reports attributing } \\
\text { outbreak to a limited } \\
\text { clustered source }\end{array}$ & $\begin{array}{c}81.57 \% \\
{[65.7-92.3](31 / 38)}\end{array}$ & $\begin{array}{c}66.67 \% \\
{[41-86.7](12 / 18)}\end{array}$ & $\begin{array}{c}94.11 \% \\
{[71.3-99.9](16 / 17)}\end{array}$ & NT & $p<0.05^{*}$ \\
\hline
\end{tabular}

* This analysis was performed without data from outbreaks attributed to tachyzoite source. NS = non significant at 0.05 . 


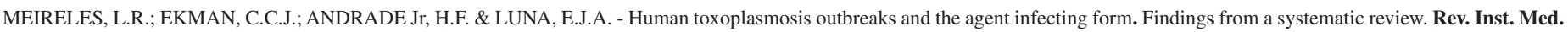
Trop. Sao Paulo. 57(5): 369-76,2015.

Table 3

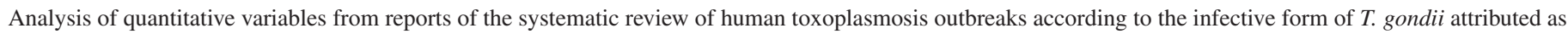
source

\begin{tabular}{|c|c|c|c|c|c|}
\hline \multirow{2}{*}{$\begin{array}{l}\text { Variable attributed by } \\
\text { author }\end{array}$} & \multirow{2}{*}{$\begin{array}{c}\text { Total } \\
\text { Mean } \pm \text { S.D. } \\
(\mathrm{n})\end{array}$} & \multicolumn{3}{|c|}{ Infective form } & \multirow{2}{*}{ Significance } \\
\hline & & Oocysts & Cysts & Tachyzoites & \\
\hline $\begin{array}{l}\text { Numbers of confirmed } \\
\text { cases }\end{array}$ & $\begin{array}{c}37.7 \pm 62,3 \\
(38)\end{array}$ & $\begin{array}{c}64.3 \pm 79.0 \\
(18)\end{array}$ & $\begin{array}{c}15.2 \pm 28.1 \\
(17)\end{array}$ & $\begin{array}{l}5.0 \pm 4.4 \\
\text { (3) }\end{array}$ & $p<0.05$ \\
\hline $\begin{array}{l}\text { Proportion of infected } \\
\text { cases in population at } \\
\text { risk }\end{array}$ & $\begin{array}{c}39.8 \pm 24,4 \\
(30)\end{array}$ & $\begin{array}{c}32.3 \pm 25.9 \\
(14)\end{array}$ & $\begin{array}{c}45.5 \pm 23.7 \\
(13)\end{array}$ & $\begin{array}{l}50.7 \pm 9 \\
(3)\end{array}$ & NS \\
\hline $\begin{array}{l}\text { Proportion of reported } \\
\text { symptomatic cases }\end{array}$ & $\begin{array}{c}81.5 \pm 21.5 \\
(35)\end{array}$ & $\begin{array}{c}77.7 \pm 23.2 \\
(17)\end{array}$ & $\begin{array}{c}85.3 \pm 20.0 \\
(16)\end{array}$ & $\begin{array}{c}83 \pm 21.5 \\
(2)\end{array}$ & NS \\
\hline $\begin{array}{l}\text { Numbers of persons at } \\
\text { risk in the outbreak }\end{array}$ & $7532.6 \pm 3944(30)$ & $\begin{array}{c}16069 \pm 54414 \\
(14)\end{array}$ & $\begin{array}{c}75.2 \pm 152.6 \\
(13)\end{array}$ & $\begin{array}{c}11 \pm 11.2 \\
(3)\end{array}$ & NS \\
\hline $\begin{array}{l}\text { Incubation period in } \\
\text { days }\end{array}$ & $\begin{array}{c}20.2 \pm 19.9 \\
(17)\end{array}$ & $\begin{array}{l}20.0 \pm 7.1 \\
\quad(4)\end{array}$ & $\begin{array}{l}11.4 \pm 6.7 \\
(11)\end{array}$ & $\begin{array}{c}34 \pm 5.79 \\
(2)\end{array}$ & $p<0.001$ \\
\hline
\end{tabular}

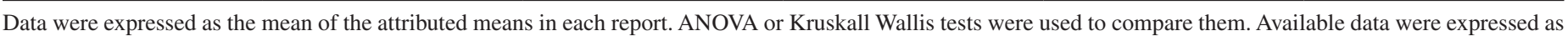
mean and standard deviation (S.D.). NS = non-significant.
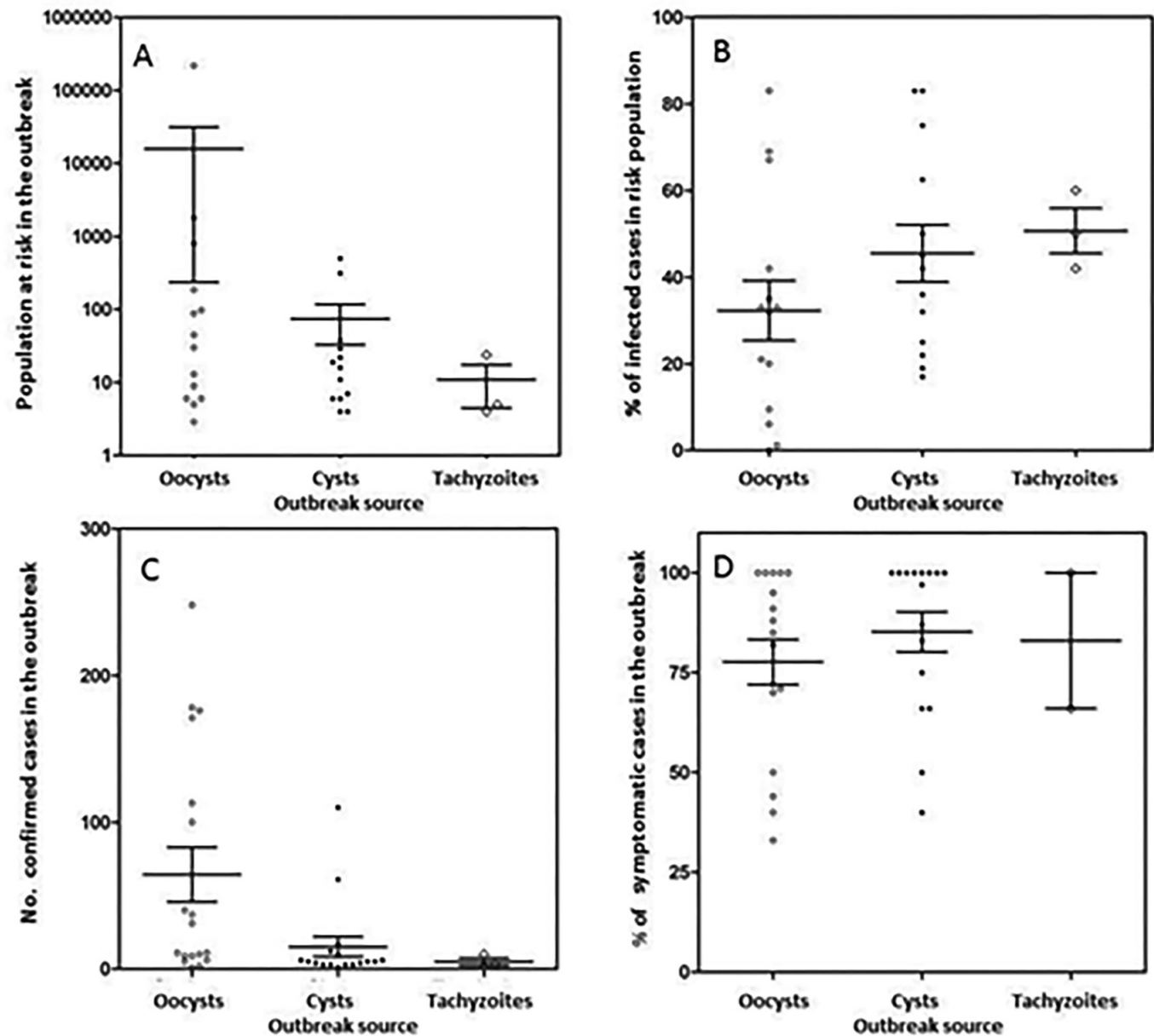

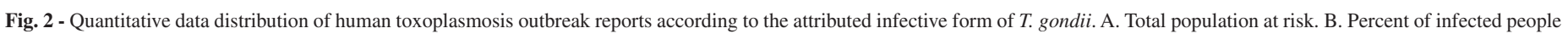
in the risk population. C. Number of confirmed cases. D. Number of symptomatic cases. Bars represent mean plus standard deviation of the sample. See Table 3 for statistical analysis. 


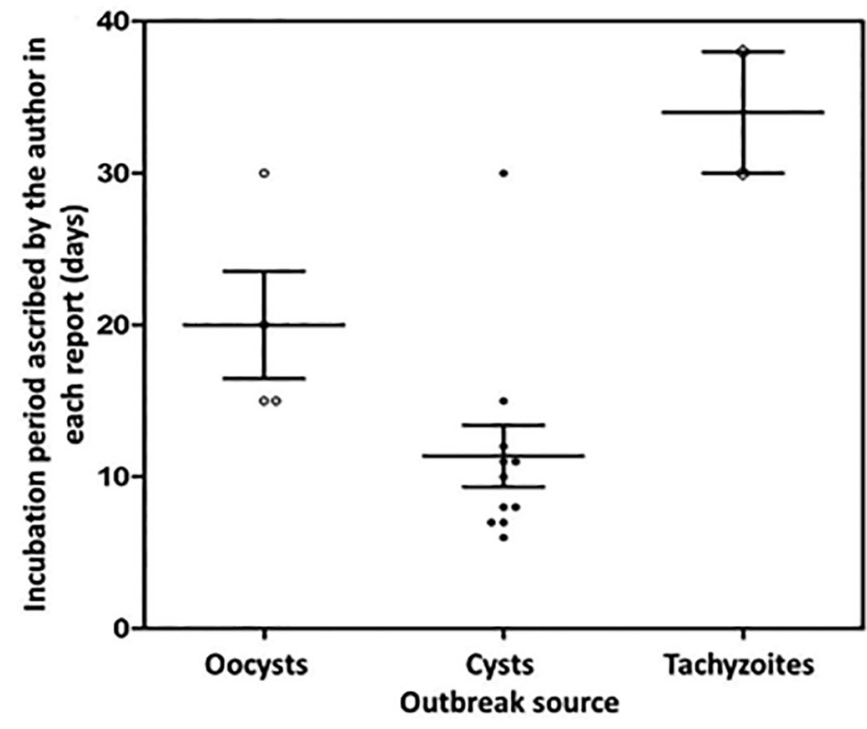

Fig. 3 - Distribution of reported incubation period in human toxoplasmosis outbreaks according to attributed infective form of $T$. gondii. Data from oocysts attributed reports was available only for meal-related outbreaks. Bars represent mean plus standard deviation of the sample.

of gender association with $T$. gondii infection in meat processing or butchering ${ }^{27}$, but this factor is much more related to chronic exposure to cyst-infected meat than to the conditions found in outbreaks, usually with a unique exposure to a detectable source.

No age-related risk was observed in our study. Older groups presented an increased seroprevalence of toxoplasmosis by cumulative exposure, a fact referenced by several authors ${ }^{27}$. The amount of ingested food could result in a bias in the age effect, which could be less important in younger groups, who tend to ingest a lower volume of food, but we have failed to find these effects in the outbreaks, probably due to the small number of those age groups. Children also could be more affected by poor hygiene habits, geophagy and environmental exposure, which are usually referenced in oocyst attributed outbreaks ${ }^{42}$. The ingestion of raw or undercooked meat could vary in age groups, usually being more frequent in food habits of older groups and the main cause of infection in pregnant women in Europe ${ }^{10}$. None of those effects were observed in the outbreak reports in our study.

Geographical distribution showed that the reports were more frequently described in the Americas, probably due to awareness of medical and research staff that resulted in more outbreaks detected and described, a phenomenon elsewhere described and extensively discussed ${ }^{16}$.

Results on affected or in risk populations were not surprising. The population data was proportional to the dispersion of the infective form in the environment, with small groups in outbreaks ascribed to cysts or tachyzoites, which were related to a common and restricted food source, and large populations in dispersed outbreaks associated with water contamination. In our review, some clustered outbreaks were associated with transmission by oocysts, due to contamination of a raw vegetable or cereal meal, as described elsewhere ${ }^{42}$. Those outbreaks allowed the determination of the incubation period when the oocyst was the source of $T$. gondii infection.
Water associated outbreaks ascribed to oocysts were so dispersed that authors fail to define an incubation period, however, cyst attributed outbreaks presented a longer incubation period. Those findings could also be related to the infectivity of oocysts and bradyzoites of T. gondii for intermediate hosts as reported elsewhere ${ }^{19,20} . T$. gondii has adapted to a tissue cyst-oral route in carnivores ${ }^{19}$, thus, it is not surprising that cyst attributed outbreaks had a shorter incubation period. For cats, the time needed for shedding of oocysts after primary infection (prepatent period) also varies with the stage of the $T$. gondii ingested ${ }^{18,19}$. The prepatent period after ingesting bradyzoites is short (3-10 days) while it is long (18 days or longer) after ingesting oocysts or tachyzoites ${ }^{18}$. Those findings were similar to the incubation period of cyst-associated outbreaks reported in our systematic review.

Symptomatology could be also related to the parasite burden or virulence of infecting strains ${ }^{14}$, but the proportions of symptomatic cases were similar in the three types of outbreaks, demonstrating that the infective form of $T$. gondii did not affect the clinical symptoms of infected individuals.

An important issue in all outbreak reports is the accuracy of the serological diagnosis in acute toxoplasmosis. The conventional serology techniques by detection of IgM or IgG may be confusing due to presence of asymptomatic individuals, which are reagent for both $\operatorname{IgM}$ and $\operatorname{IgG}$ tests. Actually, these individuals probably present chronic toxoplasmosis which may just be elucidated by $\operatorname{IgG}$ avidity. Therefore, IgG avidity assays could be included in the outbreak evaluation to enhance the accurate diagnosis of acute infection ${ }^{22,36}$.

We have failed to demonstrate any relationship between the geographical distribution of the outbreaks with disease severity. Although most of the outbreaks have been described in the Americas, there was no association of those outbreaks with the prevalence of a possibly more virulent $T$. gondii strain in the region.

Toxoplasmosis outbreaks are common occurrences in public health and usually anecdotally reported, but the careful analysis of cases, their distribution and the determination of the extent of the outbreak provide clues about the ascribed source of the infection. The knowledge of the infection source is essential for adequate preventive measures, especially when the contamination of a large water reservoir is implicated with a large population at risk, and an increased incidence of $T$. gondii infection.

\section{RESUMO}

\section{Surtos de toxoplasmose humana e a forma infectante do agente. Achados de revisão sistemática}

Toxoplasmose, infecção zoonótica altamente prevalente no mundo, é transmitida pela ingestão de oocistos em água e solo ou cistos teciduais em carne crua ou mal cozida. Um debate em andamento é se há diferenças nas características clínicas e epidemiológicas de surtos devido a uma ou outra forma infectante do agente. Realizamos revisão sistemática a partir de 437 relatos de surtos da doença, selecionando 38 artigos completos que descreveram a forma infectante do Toxoplasma com dados clínicos e epidemiológicos. Não houve seleção por gênero ou faixa etária nos surtos, descritos mais frequentemente nas Américas. Quantidade maior de indivíduos foi afetada quando oocistos, associados com solo ou 
água contaminados com fezes de gato, foram considerados a fonte de transmissão. O início dos sintomas ocorreu mais precocemente quando a infecção foi atribuída a cistos na carne (11,4 \pm 6,7 dias) com distribuição temporal nítida de casos, embora um aspecto mais amplo e prolongado de novos casos foi observado quando oocistos na água foram a fonte de infecção (20 \pm 7 dias, $p<0.001)$. Essas informações podem ser úteis no desenvolvimento e implantação de estratégias de controle.

\section{ACKNOWLEDGEMENTS}

Authors affiliations: Institute of Tropical Medicine of São Paulo, University of São Paulo (Luciana R. Meireles, Claudio C.J. Ekman, Heitor F. Andrade Jr. \& Expedito J.A. Luna) and School of Medicine, University of São Paulo (Heitor F. Andrade Jr.). All authors contributed equally in the design, execution and writing of this manuscript. The authors fail to find any conflicts of interests in this work. This work was partially supported by grants from the Laboratório de Investigação Médica do Hospital das Clínicas da Faculdade de Medicina, USP (LIMHCFMUSP-49). We gratefully thank the cooperation of the SIBI-USP staff for support during report recoveries. C. C. J. Ekman uses this work as part of his Tropical Medicine M.Sc. degree. H. F. Andrade Jr. is a fellow from CNPq.

\section{REFERENCES}

1. Balasundaram MB, Andavar R, Palaniswamy M, Venkatapathy N. Outbreak of acquired ocular toxoplasmosis involving 248 patients. Arch Ophthalmol. 2010;128:28-32.

2. Benenson MW, Takafuji ET, Lemon SM. Oocyst-transmitted toxoplasmosis associated with ingestion of contaminated water. N Engl J Med. 1982;307:666-9.

3. Bonametti AM, Passos JN, da Silva EM, Bortoliero AL. Outbreak of acute toxoplasmosis transmitted thru the ingestion of ovine raw meat. Rev Soc Bras Med Trop. 1996;30:215.

4. Bowie WR, King AS, Werker DH, Isaac-Renton JL, Bell A, Eng SB, et al. Outbreak of toxoplasmosis associated with municipal drinking water. The BC Toxoplasma Investigation Team. Lancet. 1997;350:173-7.

5. Carellos EV, de Andrade GM, Vasconcelos-Santos DV, Januário JN, Romanelli RM, Abreu MN, et al. Adverse socioeconomic conditions and oocyst-related factors are associated with congenital toxoplasmosis in a population-based study in Minas Gerais, Brazil. PLoS One. 2014;9:e88588.

6. Carmo EL, Póvoa MM, Monteiro NS, Marinho RR, Nascimento JM, Freitas SN, et al. Surto de Toxoplasmose humana no Distrito de Monte Dourado, Município de Almeirim, Pará, Brasil. Rev Pan-Amaz Saude. 2010;1:61-6.

7. Center for Disease Control, Department of Health, Education and Welfare. ToxoplasmosisPennsylvania. MMWR.1975;24:85-6.

8. Chiari CA, Neves DP. Toxoplasmose humana adquirida através da ingestão de leite de cabra. Mem Inst Oswaldo Cruz. 1984;79:337-40.

9. Choi WY, Nam HW, Kwak NH, Huh W, Kim YR, Kang MW, et al. Foodborne outbreaks of human toxoplasmosis. J Infect Dis. 1997;175:1280-2.

10. Cook AJ, Gilbert RE, Buffolano W, Zufferey J, Petersen E, Jenum PA, et al. Sources of Toxoplasma infection in pregnant women: European multicentre case-control study. European Research Network on Congenital Toxoplasmosis. BMJ. 2000;321:142-7.

11. de Almeida MAB, de Alencar LR, do Carmo GMI, de Araújo WN, Garcia MHO, Reis AKV, et al. Surto intra familiar de toxoplasmose, Santa Vitória do Palmar-RS, Julho de 2005. Boletim Eletrônico Epidemiológico. 2006. Available from: http://portalsaude. saude.gov.br/images/pdf/2014/julho/18/Ano06-n03-surto-familiar-toxoplasmose-rscompleto.pdf
12. de Moura L, Bahia-Oliveira LM, Wada MY, Jones JL, Tuboi SH, Carmo EH, et al. Waterborne toxoplasmosis, Brazil, from field to gene. Emerg Infect Dis. 2006;12:3269.

13. De Silva LM, Mulcahy DL, Kamath KR. A family outbreak of toxoplasmosis: a serendipitous finding. J Infect. 1984;8:163-7.

14. Demar M, Ajzenberg D, Maubon D, Djossou F, Panchoe D, Punwasi W, et al. Fatal outbreak of human toxoplasmosis along the Maroni River: epidemiological, clinical, and parasitological aspects. Clin Infect Dis. 2007;45:e88-95.

15. Doganci L, Tanyuksel M, Araz ER, Besirbellioglu BA, Erdem U, Ozoguz CA, et al. A probable outbreak of toxoplasmosis among boarding school students in Turkey. Clin Microbiol Infect. 2006;12:672-4.

16. Dubey JP, Lago EG, Gennari SM, Su C, Jones JL. Toxoplasmosis in humans and animals in Brazil: high prevalence, high burden of disease, and epidemiology. Parasitology. 2012;139:1375-424

17. Dubey JP, Lindsay DS, Speer CA. Structures of Toxoplasma gondii tachyzoites, bradyzoites, and sporozoites and biology and development of tissue cysts. Clin Microbiol Rev. 1998;11:267-99.

18. Dubey JP. Advances in the life cycle of Toxoplasma gondii. Int J Parasitol. 1998;28:101924.

19. Dubey JP. Comparative infectivity of oocysts and bradyzoites of Toxoplasma gondii for intermediate (mice) and definitive (cats) hosts. Vet Parasitol. 2006;140:69-75.

20. Dubey JP. Toxoplasmosis - a waterborne zoonosis. Vet Parasitol. 2004;126:57-72.

21. Eduardo MBP, Katsuya EM, Ramos SRTS, Pavanello ORP, Brito SN, Madalosso G Investigação do surto de toxoplasmose associado ao consumo de prato à base de carne. crua ("steak tartar"), nos municípios de São Paulo e Guarujá, SP, Novembro de 2006. BEPA. 2007;4(41). [cited 2012 Set 14]. Available at: http://www.cve.saude. sp.gov.br/agencia/bepa41_toxoplas.htm

22. Ekman CCJ, Chiossi MF, Meireles LR, Andrade Júnior HF, Figueiredo WM, Marciano MA, et al. Case-control study of an outbreak of acute toxoplasmosis in an industrial plant in the state of São Paulo, Brazil. Rev Inst Med Trop Sao Paulo. 2012;54:239-44

23. Fertig A, Selwyn S, Tibble MJK. Tetracycline treatment in a food borne outbreak of toxoplasmosis. Br Med J. 1977;1(6068):1064.

24. Gattás VL, Nunes EM, Soares ALB, Pires MA, Pinto PLS, de Andrade HF. Acute toxoplasmosis outbreak at Campus of the University of Sao Paulo related to food or water oocyst contamination. Annals of the International Conference on Emerging Infectious Diseases. Atlanta: Georgia; 2000. p. 135.

25. Higgins JPT, Green S. Cochrane handbook for systematic reviews of interventions Version 5.0.2 [updated September 2009]. London: The Cochrane Collaboration; 2009. Available at: http://www.cochrane-handbook.org

26. Humphreys H, Hillary IB, Kiernan T. Toxoplasmosis: a family outbreak. Ir Med J. 1986;79:191

27. Jones JL, Dargelas V, Roberts J, Press C, Remington JS, Montoya JG. Risk factors for Toxoplasma gondii infection in the United States. Clin Infect Dis. 2009;49:878-84.

28. Kean BH, Kimball AC, Christenson WN. An epidemic of acute toxoplasmosis. JAMA 1969;208:1002-4.

29. Luft BJ, Remington JS. Acute Toxoplasma infection among family members of patients with acute lymphadenopathic toxoplasmosis. Arch Intern Med.1984;144:53-6.

30. Madeira A, Búrigo MJ. Surto de toxoplasmose no município de Agronômica em Santa Catarina. Estudos e Avaliação [Internet]. Florianópolis: Secretaria de Estado de Saúde, s.d. [cited 2012 Sept 14]. Available from: http://www.dive.sc.gov.br/conteudos/ articulacao_tecnica/toxoplasmose-boletim-epidemiológico.pdf 
31. Magaldi C, Elkis H, Pattoli D, Coscina AL. Epidemic of toxoplasmosis at a university in São-José-dos Campos, S.P. Brazil. 1. Clinical and serologic data. Rev Latinoam Microbiol Parasitol (Mex). 1969;11:5-13.

32. Masur H, Jones TC, Lempert JA, Cherubini TD. Outbreak of toxoplasmosis in a family and documentation of acquired retinochoroiditis. Am J Med.1978;64:396-402.

33. McDonald JC, Gyorkos TW, Alberton B, MacLean JD, Richer G, Juranek D. An outbreak of toxoplasmosis in pregnant women in northern Quebec. J Infect Dis. 1990;161:76974.

34. Minot S, Melo MB, Li F, Lu D, Niedelman W, Levine SS, et al. Admixture and recombination among Toxoplasma gondii lineages explain global genome diversity. Proc Natl Acad Sci USA. 2012;109:13458-63.

35. Palanisamy M, Madhavan B, Balasundaram M, Andavar R, Venkatapathy N. Outbreak of ocular toxoplasmosis in Coimbatore, India. Indian J Ophthalmol. 2006;54:129-31.

36. Renoiner EIM, Siqueira AA, Garcia MH, Alves RM, Cardoso ME, Ferreira ABPL, et al. Surto de toxoplasmose adquirida, Anápolis-GO, fevereiro de 2006. Boletim Eletrônico Epidemiológico 2007. Available from: http://portalsaude.saude.gov.br/ images/pdf/2014/julho/16/Ano07-n08-toxoplasmose-adquirida-go-completo.pdf

37. Robson JMB, Wood RN, Sullivan JJ, Nicolaides NJ, Lewis BR. A probable foodborne outbreak of toxoplasmosis. Communicable Diseases Intelligence. 1995;19:517-22.
38. Sacks JJ, Delgado DG, Lobel HO, Parker RL. Toxoplasmosis infection associated with eating undercooked venison. Am J Epidemiol. 1983;118:832-8.

39. Sacks JJ, Roberto RR, Brooks NF. Toxoplasmosis infection associated with raw goat's milk. JAMA. 1982;248:1728-32.

40. Shenep JL, Barenkamp SJ, Brammeier SA, Gardner TD. An outbreak of toxoplasmosis on an Illinois farm. Pediatr Infect Dis.1984;3:518-22.

41. Skinner LJ, Timperley AC, Wightman D, Chatterton JMW, Ho-Yen DO. Simultaneous diagnosis of toxoplasmosis in goats and goatowner's family. Scand J Infect Dis. 1990;22:359-61.

42. Stagno S, Dykes AC, Amos CS, Head RA, Juranek DD, Walls K. An outbreak of toxoplasmosis linked to cats. Pediatrics. 1980;65:706-12.

43. Tenter AM, Heckeroth AR, Weiss LM. Toxoplasma gondii: from animals to humans. Int J Parasitol. 2000;30:1217-58.

44. Teutsch SM, Juranek DD, Sulzer A. Epidemic toxoplasmosis associated with infected cats. N Engl J Med. 1979;300:695-9.

Received: 16 March 2015

Accepted: 9 June 2015 